ANETA GOP

Instytut Pedagogiki

Akademia Pedagogiki Specjalnej im. M. Grzegorzewskiej

Warszawa
Forum Pedagogiczne

2016/2 cz. 1

Wpłynęło: 31.12.2015

Zatwierdzono do druku: 24.05.2016

DOI: $10.21697 / \mathrm{fp} .2016 .2 .17$

\title{
ETYKA INTEGRALNA KENA WILBERA. ZARYS IDEI I JEJ PEDAGOGICZNE IMPLIKACJE
}

Streszczenie: Artykuł porusza problem etyki integralnej w ujęciu współczesnego amerykańskiego filozofa Kena Wilbera. Tekst poświęcony jest przedstawionej przez niego analizie stadiów rozwoju moralnego. Ponadto przybliża podstawowe pojęcia z zakresu etyki integralnej i dyskutuje na temat możliwych aplikacji tego modelu w współczesnym polskim dyskursie pedagogicznym.

Słowa kluczowe: Ken Wilber, stadia rozwoju moralnego, etyka integralna, wartości.

\section{Wstęp}

Ludzkość boryka się współcześnie ze złożonością problemów etycznych, co wiąże się z wieloma zjawiskami, w szczególności z hybrydyzacją i wymieszaniem kultur (transkulturowością), transnacjonalizacją i interdyscyplinarnością. Przykłady odzwierciedlające skomplikowanie tej sytuacji w odniesieniu do sfery moralnej można mnożyć w nieskończoność.

W związku z powyższym na gruncie wielu nauk postuluje się stanowiska integrujące różne perspektywy widzenia kwestii moralnych i etycznych. W odniesieniu do rozwoju moralnego i modelowania postępowania etycznego należy wziąć pod uwagę - na równi z ujęciem jednostkowym - także pytania powstające na poziomach kulturowym i systemowym. Dopiero bowiem dzięki całościowemu ujęciu będzie można rozwikłać dylematy moralności i etyki. Propozycję koncepcji scalającej w sobie zróżnicowane perspektywy rozumienia problemów etyczno-moralnych przedstawił w ostatnim czasie amerykański filozof Ken Wilber.

\section{Ken Wilber - twórczość i poglądy w zarysie}

Kenneth Earl Wilber jest twórcą teorii integralnej (integral theory) i jednym z najbardziej wpływowych współczesnych filozofów amerykańskich. Jak pisze polska 
badaczka twróczości Wilbera, Marzanna B. Kielar, został on w 1987 roku zaliczony przez Daniela Golemana „do grona wielkich teoretyków ludzkiej świadomości, takich jak Ernst Cassier, Mircea Eliade czy Gregory Bateson” (Kielar 2012, s. 12). Jego nazwisko wymienia się obok największych teoretyków i badaczy rozwoju ludzkiego, takich jak: Jean Piaget, Lawrence Kohlberg, Howard Gardner, Michael L. Commons czy Robert Kegan. Wilber jest autorem kilkuset artykułów i ponad 20 książek naukowych i popularnonaukowych, jego twórczość doczekała się tłumaczeń na około 30 języków. Następujące jego prace są dostępne w języku polskim: Psychologia integralna. Świadomość, duch, psychologia, terapia (2002), Krótka historia wszystkiego (1997), Spektrum świadomości (2009), Niepodzielone. Wschodnie izachodnie teorie rozwoju osobowości (1996), Małżeństwo rozumu z dusza. Integracja nauki i religii (2008).

Wilberowski nurt integralny skupiony jest w Polsce wokół edukacji integralnej AQAL (Piotr Błajet, Beata Przyborowska) i integralnego pluralizmu metodologicznego (integral metodological pluralism), metody badań naukowych uwzględniającej osiem rodzin metod badawczych (Kielar 2012; Kielar, Gop 2012). Idee integralne sięgają korzeniami prac Bronisława Ferdynanda Trentowskiego i współtworzą obecnie kilka nurtów pedagogicznych, takich jak: ekologia pedagogiczna (Zbigniew Kwieciński), ekologia dialektyczna (Lech Witkowski, Wiesław Andrukowicz, Ryszard Maciej Łukaszewicz), edukacja holistyczna i systemowa (Wiktor Żłobicki, Bogusław Śliwerski, Roman Schulz), nurt propagujący ideał wiedzy zintegrowanej (Z. Kwieciński, B. Śliwerski, W. Żłobicki, Rafał Włodarczyk, Adam Chmielewski, Maria Dudzikowa, Adam Grobler i in.) (Kielar 2014; Gop 2015).

Trudnym $z$ wielu względów zadaniem jest zrekapitulowanie głównych poglądów Wilbera bez narażenia się na uproszczenia. W niniejszym paragrafie przytoczę jedynie niektóre główne tezy, rozszerzając znaczenie kilku z nich. Pierwsze polskojęzyczne przedstawienie idei Wilbera stanowi książka Kielar (2012), do której niejednokrotnie odwołuję się w niniejszym tekście.

Wilber w logiczny sposób zespoił i ustrukturyzował idee wschodniej i zachodniej myśli naukowej, nadając skonstruowanej w ten sposób wizji rzeczywistości miano integralnej, oznaczającej, za Jeanem Gebserem, podejście wszechstronne, nielekceważące, wszechobejmujące. Wyraża się ono we włączaniu częściowych prawd wielu ugruntowanych naukowo podejść, przez stosowanie metody orientujących uogólnień (orienting generalizations) i wyłanianiu silnych konkluzji (strudy conclusions). „Jeśli przyglądamy się różnym obszarom ludzkiej wiedzy - od fizyki poprzez biologię, psychologię, socjologię, teologię po religię - wyłaniają się pewne szerokie, ogólne tematy, co do których w rzeczywistości istnieje tylko niewielka różnica zdań. Za przykład weźmy sferę rozwoju moralnego. Nie wszyscy zgadzają się ze szczegółami stopni Lawrence’a Kohlberga ani też ze szczegółami zaproponowanymi w nowym ujęciu Carol Gilligan. Ale istnieje powszechna i całkowita zgoda co do tego, że rozwój moralny przechodzi przez co najmniej trzy główne stopnie. [...] To właśnie orientujące uogólnienia pokazują nam, przy niemal powszechnej 
zgodzie, gdzie leżą liczące się lasy, nawet jeśli nie możemy zgodzić się co do tego, ile jest w nich drzew" (Wilber 1997, s. 35-36). Uznane twierdzenia - silne konkluzje, wyprowadzane $z$ wielu dziedzin (od tradycyjnych nauk duchowych po najnowsze nauki obiektywne), posłużyły Wilberowi do stworzenia systematycznej wizji integralnej, swoistej metateorii. Zintegrował premodernistyczną ideę poziomów istnienia (materia-umysł-duch) z modernistyczną „wielką trójką” (sztuka-moralność-nauka) oraz postmodernistycznym konstruktywizmem (Kielar 2012).

Wilber mówi o holonicznej ${ }^{1}$ naturze rzeczywistości, która stanowi samotworzącą się i ewoluującą całość. Holony, całości będące częściami większych całości, zawierają się w sobie, tworząc holarchie i ewoluując przechodzą przez poziomy: fizyczne (przedlogiczne), mentalne (logiczne), osiągając poziom duchowy (translogiczny). Ewolucja, jak zaznacza Wilber, rozwinęła już materię nieożywioną wraz z materią ożywioną, umysł konceptualny i zaczyna już rozwijać duchowe, najwyższe poziomy (Kielar 2012).

Porównując kilkaset modeli rozwojowych z wielu obszarów wiedzy (wielodziedzinowe holarchie), od psychologii rozwojowej, teorii systemów, ewolucji biologicznej i kosmicznej, po filozoficzne i duchowe tradycje, Wilber zauważył, iż istnieją cztery różne rodzaje holarchii. Owe holarchie opisują holon w jego wymiarach wewnętrznym i zewnętrznym oraz jednostkowym i kolektywnym. Każdy aspekt rzeczywistości da się opisać przy pomocy owych czterech perspektyw ${ }^{2}$. Przykładowo, każdy człowiek posiada indywidualną, subiektywną perspektywę (Japerspektywę); będąc częścią większej całości, np. danej grupy społecznej, posiada wspólnotową, kolektywną perspektywę (My-perspektywę). Gdy spoglądamy na człowieka w wymiarze obiektywnych zachowań, uruchamiana jest perspektywa behawioralna (To-perspektywa), gdy patrzymy na niego jako na część systemu społecznego i środowiska, uruchamiana jest perspektywa systemowa (Te-perspektywa). Rozwinięciem tych perspektyw jest złożony model badań IMP (integralny pluralizm metodologiczny). Warto nadmienić, iż Wilber skonstruował wysoko zaawansowany model rozwoju świadomości, wychodzący daleko dalej poza poziomy rozwoju poznawczego Piageta. Jego teoria bywa z powodzeniem aplikowana w wielu obszarach wiedzy, od duchowości po nauki ścisłe.

\section{Etyka integralna - praktyka podstawowego dobra}

Etyka integralna stanowi praktyczną aplikację paradygmatu integralnego, która w najprostszym ujęciu może być rozumiana jako „sztuka bycia dobrą osobą" (Wilber i in. 2008, s. 255). Filozofia ta nie stanowi jednak prostej wykładni moralnego postępowania, tworzy jedynie szkic tego, jak indywidualnie podejmować

1 Holon - całość będąca jednocześnie częścią innej całości, bez ograniczeń w górę i w dół (Wilber 2000, s. 43).

2 O perspektywach tych szerzej mówię w kolejnym paragrafie. 
najcenniejsze i najbardziej trafne moralnie decyzje. Wilber charakteryzuje etykę integralną jako „praktykę, otwarto-domknięte, istniejące w danym momencie (moment-to-moment) ewolucyjne (rozwojowe) dążenie do ucieleśniania szczerej troski i aktualizowanie najgłębszego instynktownego doświadczenia Boga w naszych życiach oraz całym świecie" (Wilber i in. 2008, s. 255). Etyka integralna jest zatem immanentnie związana z rozwojem. Wznosi ku wyższym stadiom rozwojowym zarówno sposób postrzegania, jak i działania w odniesieniu do wszystkich czujących istnień oraz nieczujących bytów.

Rozwój moralny przebiega przez analogiczne chociażby do wzrostu poznawczego stadia: od stadium przedkonwencjonalnego do postkonwencjonalnego, i najściślej wiąże się z rozwojem intelektualnym. Integracja linii rozwoju poznawczego $\mathrm{z}$ moralnym wyraża się w precyzji umysłowej w zakresie formułowania wartości moralnych, jednakże sam rozwój poznawczy nie jest wystarczający dla rozwinięcia się moralności. Nie trudno wyobrazić sobie osobę pozbawioną kręgosłupa moralnego, jednakże wysoko rozwiniętą w linii rozwoju intelektualnego (Wilber 2006; Kelly 2015). Sytuacja odwrotna także jest możliwa; jednostka uduchowiona, cechująca się wysoką inteligencją moralną, może wykazywać niższe poziomy rozwoju poznawczego ${ }^{3}$.

Pierwsze ze wspomnianych powyżej stadiów rozwoju moralnego, przedkonwencjonalne stadium, zwane egocentryzmem etycznym, wyraża się w zachowaniach motywowanych czysto nieświadomie, dyktowanych narcystycznymi, egocentrycznymi pobudkami i popędami. Egocentryzm etyczny nabudowany jest zatem na własnej subiektywnej perspektywie i w zasadzie nie wykracza poza nią. W drugim stadium - konwencjonalnym - moralność, a wraz z nią tożsamość, rozszerzają się z perspektywy egocentrycznej (Ja) na grupową (My). Tworzy się tym samym rdzeń moralności etnocentrycznej, charakteryzującej się wyznawaniem wartości czerpanych z grupy, w której jednostka żyje. W trzecim postkonwencjonalnym stadium rozwoju moralnego tożsamość rozszerza się ponownie, tym razem z perspektywy „My” na „My wszyscy”, tworząc moralność światocentryczną, związaną m.in. z braniem odpowiedzialności za ludzi i planetę. Wzrost ten związany jest z rozwojem zdolności do dostrzegania różnorodności i odkrywania dobra przynależnego nie tylko jednostce czy rodzinie, ale wszystkim czującym istnieniom (Wilber 2006; 2007, s. 36-37; Kelly 2015). Stadia rozwoju moralnego wybiegają jednak daleko dalej poza światocentryzm, w kierunku multi-światocentrycznym i kosmocentrycznym (por. ryc. 1). Jednostka będąca na ostatnich dwóch stadiach rozwoju moralnego jest duchowo ukierunkowana (spirit-oriented) i wykazuje „uniwersalną troskę i współczucie, obejmujące całą rzeczywistość, w jej wymiarach wewnętrznym i zewnętrznym, włączywszy wszystkie czujące istnienia oraz byty

${ }^{3} \mathrm{~W}$ zakresie diagnostyki na potrzeby edukacji problem może stanowić fakt, iż nie jesteśmy w stanie ujrzeć nic ponad kształt zdolności poznawczych, ponieważ w przeciwieństwie do funkcjonowania intelektualnego nie badamy rozwoju moralnego niemal nigdy. 
(all beings and all things)" (Reynolds 2006, s. 203-204). Wilber (2005) zaznacza, iż od 50 proc. do 70 proc. ludzi na świecie osiąga co najwyżej stadium etnocentyczne.

Rycina 1. Poziomy rozwoju moralności

\begin{tabular}{|c|c|c|}
\hline KOSMOCENTRYCZNY & $\begin{array}{c}{ }^{5-O S} \\
\text { AŻ DO N-TEJ }\end{array}$ & $\begin{array}{l}\text { WSZYSTKIE } \\
\text { CZUJĄCE BYTY } \\
\text { WE WSZYSTKICH } \\
\text { ŚWIATACH }\end{array}$ \\
\hline $\begin{array}{l}\text { MULTI- } \\
\text { ŚWIATOCENTRYCZNY }\end{array}$ & 4 -OS. & $\begin{array}{l}\text { WSZYSCY LUDZIE } \\
\text { I INNE BYTY, } \\
\text { PLURALISTYCZNA }\end{array}$ \\
\hline ŚWIATOCENTRYCZNY & 3-OS. & $\begin{array}{l}\text { WSZYSCY LUDZIE, } \\
\text { UNIWERSALI- } \\
\text { STYCZNA }\end{array}$ \\
\hline ETNOCENTRYCZNY & 2-OS. & $\begin{array}{l}\text { MY, RODZINA, } \\
\text { PLEMIE, NACJA }\end{array}$ \\
\hline EGOCENTRYCZNY & $1-\mathrm{OS}$. & JA \\
\hline POZIOM & $\begin{array}{l}\text { ZŁOŻONOŚĆ } \\
\text { PERSPEKTYWY }\end{array}$ & $\begin{array}{l}\text { KONCENTRACJA, } \\
\text { ZOGNISKOWANIE }\end{array}$ \\
\hline
\end{tabular}

Źródło: Wilber i in. 2008, s. 257.

O wzroście moralnym można mówić, uwzględniwszy jego dwa kierunki przebiegu: wspomniany wcześniej wertykalny, ukazujący ewolucję etyki od stadiów egocentrycznych ku pogłębionej złożoności kierunków planetarnego i kosmocentrycznego, oraz horyzontalny, który nakierowany jest na pogłębienie współczucia i etycznej troski oraz rozszerzenie tych doznań na możliwie najwięcej płaszczyzn własnego życia, od codziennie wykonywanych aktywności po relacje z innymi ludźmi w życiu osobistym i zawodowym (Wilber i in. 2008). Można zatem wertykalnie rozwijać współczucie i troskę, biorąc za punkt wyjścia egocentryczną perspektywę i poszerzać ją na inne osoby, nacje, ludzkość, niezależnie od rasy i koloru skóry czy płci (Wilber 2007), oraz horyzontalnie, wykazując troskę i współczucie w każdym działaniu i w stosunku do wszystkich osób.

Każdy z nas, powiada Wilber, posiada podstawową intuicję moralną (basic moral intuition), która jest zasadą „chronienia i promowania największej głębi istnienia dla jak największej przestrzeni" (Wilber i in. 2008, s. 261). Głębię pojmuje się tu jako złożoność rozwojową: im organizm jest wyżej na szczeblu drabiny rozwojowej, tym jego złożoność jest większa i większa jest też jego głębia. Przestrzeń (span) jest niezależna od stadium złożoności biologicznej, za to odnosi się do rozwoju poznawczego, w szczególności do ilości uruchamianych perspektyw, od subiektywnej po intersubiektywną, obiektywną i interobiektywną. Wilber w swoim podejściu 
wprowadza do utylitarnej zasady etycznej, głoszącej jak największe dobro dla jak największej liczby istnień, wymiar głębokości rozwojowej, o którym mówi, że to właśnie on stanowi szczególnie cenny element i należy go chronić; stroni jednak od stosowania uproszczeń i wyciągania z tej zasady mylnych wniosków. To, kogo dany człowiek ceni bardziej, to kwestia wysoce indywidualna, niektóre wybory są bardziej właściwe, ale nie ma jednego - najlepszego. Ten sposób rozumienia wartości pokłada nadzieję w człowieku, wierząc, iż użyje on swojej intuicji moralnej w sposób odpowiedni dla danego momentu dziejowego/egzystencjalnego. Chociaż łatwo o pomyłkę w wyborze etycznym, Wilber mówi, że „nasza zdolność do mądrego dokonywania takich wyborów wzrasta wzdłuż rozwojowej trajektorii” (Wiber i in. 2008, s. 262), ponieważ „im wyższy stopień rozwoju, tym bardziej samoświadomy duch, tym większa samowiedza podmiotu, który na najwyższych poziomach świadomości przekracza jednostkowe ego i - zachowując w sobie jego funkcje - otwiera się na boską transcendencję, unię mistyczną" (Kielar 2012, s. 20). Dlatego też etyka integralna stanowi etykę rozwoju człowieka we wszystkich możliwych wymiarach, $\mathrm{w}$ tym także w aspekcie poznawczym. Intelekt umożliwia bowiem pojmowanie abstrakcyjnych zasad moralnych, takich jak: prawo do samostanowienia, równość człowieczeństwa, szczerość, przebaczenie, jako logicznie spójnych i uniwersalnych (Forman 2011; Murray 2008).

Etyka integralna zakłada istnienie trzech odrębnych wartości: podstawowej (ground value), wewnętrznej (intrinsic value) oraz względnej (relative value). „Wartość podstawowa odnosi się do faktu, że każde istnienie, od kwarku począwszy, przez źdźbło trawy, na istocie ludzkiej skończywszy, jest jednakowo wyrazem absolutnego Ducha, Pustki, egzystencją samą w sobie (suchness) albo świadectwem Boga ${ }^{4}$. W tym podstawowym znaczeniu każde istnienie, w szczególności każda osoba, jest nieskończenie wartościowe i w jednakowym stopniu zasługujące na etyczny wzgląd" (Wilber i in. 2008, s. 262). Istota wartości podstawowej leży w przekonaniu, które mówi, aby we wszystkich bytach i istotach postrzegać siebie jako część większej całości. Wartość ta jest rudymentarna dla dokonywania wyborów moralnych i ilekroć stoimy przed takimi wyborami, należy utrzymywać ją w świadomości.

4 Złożoność organizmów, tłumaczy Wilber, jest wyrazem ewolucyjnego uporządkowania samotworzących się i uniwersalnych struktur, powstałych z elementów pomniejszych, czyli holonów (całości/części). Koncepcję holonu zaczerpnął Wilber od węgierskiego filozofa Arthura Koestlera. Holon jest definiowany jako byt, który „będąc całością w jednym kontekście, jest jednocześnie częścią innej” (Wilber 200o, s. 27-28; por. także: Kielar 2012, s. 20-24 oraz s. 45-56). Całość (wyższy holon) wykracza poza sumę budujących ją części (niższych, względem omawianego), stanowiąc wyższą rozwojowo formę i formując znaczenie zbudowanej nowej większej całości. Przykładowo, w ćwiartce behawioralnej możemy mówić o molekule, która jest holonem, składającym się z atomów, budującym komórki, w ćwiartce indywidualnej możemy mówić o holonie, jakim jest pojęcie, na które składają się symbole zawierające się w całych zasadach (Wilber 2005). Większe i przekraczające siebie holony tworzą hierarchię lub holarchię, która integruje światy materialny, umysłowy oraz duchowy. 
„Wartość wewnętrzna odnosi się do rozwoju głębi. Im większa głębia, tym większa wartość wewnętrzna. Głębokość nie jest prostym stopniem na drabinie rozwoju, kiedy czynimy odniesienia do głębi musimy wziąć pod rozwagę wszystkie aspekty rozwoju. Wartość względna wskazuje na użyteczność w specyficznym kontekście" (Wilber i in. 2008, s. 263). Będzie ona miała zastosowanie w sytuacji, w której można będzie uratować ludzkie życie (a wszystkie są równie cenne) i w której będziemy decydowali o tym, kto reprezentuje taką wartość w większym stopniu. Etyka integralna unaocznia dylematy i przygotowuje do podejmowania decyzji trudnych, w których nie ma rozwiązań jednoznacznie dobrych i złych. W rzeczywistości niejednokrotnie stajemy przed wyborami, z których każdy jest w jakimś stopniu właściwy i musimy żyć z konsekwencjami tych wyborów. Etyka Wilbera nie stanowi zatem etyki czarno-białych dylematów moralnych; należy ją rozumieć jako etykę poruszania się w odcieniach szarości.

Rozwiązując etyczne dylematy, ludzie zadają sobie pytania: co powinnam (powinienem) zrobić? Co powinniśmy (jako diada, grupa, społeczność) zrobić, co powinno zostać zrobione? Etyka integralna podpowiada, jak klasyfikować te różne punkty odniesienia, kierując się zasadą obierania rudymentarnych perspektyw (dwóch indywidualnych: subiektywnej, oznaczanej zaimkiem (Ja) i obiektywnej, oznaczanej zaimkiem (To), a także dwóch zbiorowych: kulturowej (My) oraz systemowej (Ty)). Strukturę tą przedstawiono na poniższej rycinie.

Rycina 2. Niektóre aspekty czterech ćwiartek integralnej etyki

\begin{tabular}{|c|c|}
\hline Górna lewa & Górna prawa \\
\hline Self i świadomość & Mózg i organizm \\
\hline Indywidualna - wnętrze & \\
Doświadczenia & \\
Subiektywna \\
Prawdomówność & Indywidualna - zewnętrze \\
& $\begin{array}{c}\text { Zachowania } \\
\text { Obiektywna } \\
\text { Prawda }\end{array}$ \\
\hline JA & TO \\
\hline MY & TE \\
\hline Zbiorowa - Wnętrze & Zbiorowa - Zewnętrze \\
Kultury & Systemy \\
Intersubiektywna & Interobiektywna \\
Sprawiedliwość & Funkcjonalne przystosowanie \\
\hline Kultura i światopogląd & System społeczny i środowisko \\
\hline Dolna lewa & Dolna prawa \\
\hline
\end{tabular}

Źródło: Esbjörn-Hargens, Wilber 2006, s. 526. 
Zadając pytanie: Co powinnam (powinienem) zrobić w danej sytuacji spogląda się na daną rzeczywistość z perspektywy intencjonalnej (indywidualnej, podmiotowej, subiektywnej; ćwiartka górna lewa). Subiektywne podejście łączy się z działaniem, czyli perspektywą behawioralną (Co robię?) (obiektywną; ćwiartka górna prawa). W trakcie dyskusji o wyborach etycznych z poziomu zbiorowości (Co powinniśmy zrobić?) uruchamiana jest perspektywa kulturowa (intersubiektywna; ćwiartka dolna lewa), przy tworzeniu zaś zasad i powinności odnośnie moralnego postępowania (Co musimy zrobić?) uruchamiamy perspektywę systemową (interobiektywną).

Rycina 3. Cztery ćwiartki integralnej etyki

\begin{tabular}{|c|c|}
\hline INDYWIDUALNA & INDYWIDUALNA \\
MORALNOŚĆ & ZACHOWANIA \\
Co powinnam (powinienem) zrobić & Co robię? \\
w danej sytuacji? & \\
\hline ZBIOROWA & ZBIOROWA \\
ETYKA & PRAWO \\
Co powinniśmy zrobić? & Co musimyzrobić? \\
\hline
\end{tabular}

Źródło: Wilber i in. 2008, s. 264.

Perspektywa intencjonalna (Ja) stanowi przestrzeń etycznego poznania (zrozumienia), jest obszarem etycznej świadomości wyrażonej m.in. w osobistym poczuciu odpowiedzialności, winy czy pewności dokonania właściwego wyboru. Perspektywa subiektywna to pole etyki intra-psychicznej, w której znajduje się miejsce na udzielenie sobie odpowiedzi na pytania o to: jak traktuję samego siebie? Czy jestem ze sobą szczery, czy znęcam się nad sobą lub zaniedbuję siebie? Czy jestem odpowiedzialny, współczujący w stosunku do samego siebie, w tych momentach, w których wymaga tego sytuacja? Praktykami stosowanymi na tym poziomie są osobista refleksja oraz praca z cieniem. Etyka pracy z cieniem jest wzięciem odpowiedzialności za psychologiczne projekcje, nierozwiązane konflikty, uświadomieniem ich sobie. Jest rownież nierozerwalnym elementem prawdziwego wzrostu moralnego.

Perspektywa behawioralna (To) przynależy etycznemu traktowaniu własnego ciała, w czym pomocne jest metaforyczne ujęcie ciała jako świątyni. Przejawami etycznych zachowań mogą być ćwiczenia, przestrzeganie diety, dbanie o wygląd. Etyka integralna niekoniecznie sprzeciwia się takim praktykom, jak modyfikacje ciała, włącznie z chirurgią plastyczną, jednakże ustanawia te praktyki raczej w sposobach wyrazu etyki prekonwencjonalnej aniżeli wyższej poziomowo postkonwencjonalnej. Etyczny wybór traktowania rzeczy zawiera się także w tej perspektywie, 
może on być przykładowo sentymentalny lub instrumentalny i dotyczyć wielu dóbr: wytworów natury, dzieł sztuki i architektury czy przedmiotów użytkowych.

Perspektywa kulturowa (My) stanowi wyraz intersubiektywnych poglądów i związana jest z pytaniami: W jaki sposób powinnam/powinienem traktować ciebie oraz w jaki sposób powinniśmy się wzajemnie traktować? Przestrzeń etycznej praktyki w tym wymiarze dotyczy zarówno osób będących w bliskich relacjach (rodzinnych, przyjacielskich czy seksualnych), jak i w relacjach dalszych (koleżeńskich i pracowniczych). Przestrzeń ta rozwija się i włącza także relacje przypadkowe, np. ze sprzedawcą, osobą, obok której siedzimy w autobusie, ze zwierzęciem, ale także z każdym potencjalnym My - narodowym, globalnym, gatunkowym (Wilber i in. 2008). Na każdym poziomie rozwoju w perspektywie My zmienia się sposób, w jaki komunikuje się etyczną troskę.

Perspektywa systemowa Te wyraża się w pytaniu: W jaki sposób troszczymy się o systemy i środowisko, od których zależy nasze życie? W perspektywie tej zawierają się: 1) środowisko naturalne i ekosystemy; 2) technologia infrastruktury, transportu, internetu itp.; 3) dom; 4) rząd; 5) szkoły; 6) systemy zdrowotny czy ekonomiczny; 7) organizacje biznesowe i 8) wymiar sprawiedliwości (Wilber i in. 2008, s. 268).

Głównymi pytaniami z poziomu systemowego, przed którymi stoi jednostka, są: W jaki sposób moje zachowanie oddziałuje na system? Jak powinnyśmy organizować systemy? Z punktu widzenia etycznych działań związanych z systemami możemy troszczyć się o społeczną aktywizację, cywilną odpowiedzialność w podejmowaniu działań, takich jak inwestowanie w odnawialne źródła energii czy recykling. Etyczne praktyki z poziomu systemowego mogą też obejmować przestrzeń personalną; dotyczyć to będzie sytuacji, w której etycznie zaprojektujemy przykładowo obszar mieszkalny.

Rodzaj i głębokość etycznych wyborów są zdeterminowane ilością perspektyw, jakie podmiot poznający potrafi utrzymywać w świadomości. Warto podkreślić, że uzyskując zdolność do obierania nowej perspektywy, osoba nie zatraca tej rozwojowo niższej, a będąc z kolei na najwyższym poziomie rozwoju (moralności kosmocentrycznej), jednostka jest zdolna do obierania przynajmniej czterech perspektyw. Rozwijane multiperspektywiczności poznania związane jest $\mathrm{z}$ formą integracji poznawczej zakotwiczonej w stadium wizji-logiki (vision-logic) rozwoju poznawczego - rozumowaniem syntetyzującym rozwinięte w wysokim stopniu zdolności poznawcze z wyobraźnią i wglądem (Kielar 2012). Wówczas ego łączy się z jungowskim „cieniem”, a proces uświadamiania sobie cienia i integrowania go z ego stanowi podstawę dokonywania trafnych moralnie osądów (Kelly 2015).

\section{Kształtowanie moralności integralnej}

Wzrost moralno-etyczny jest istotny dla każdego obszaru funkcjonowania człowieka. Jako przykład obierzmy edukację biznesową, w której etyka integralna wspomagać może integrację self z kulturą i systemem organizacji. Poza nielicznymi 
wyjątkami na kierunkach kształcących przyszłą kadrę zarządzającą, główny nacisk położony jest na tzw. ścieżki prawej ręki, czyli obiektywne i mierzalne zachowania oraz rozwój systemu organizacji (Waddock 2005). Jednostki zatrudnione w organizacjach wnioskują o wartościach firmy, mając na uwadze właśnie owe obiektywnie mierzalne dane empiryczne, jak przykładowo: wydolność finansowa organizacji (perspektywa obiektywna; ćwiartka behawioralna) lub systemowe wskaźniki, czyli dochód narodowy czy wzrost ekonomiczny (perspektywa interobiektywna; ćwiartka systemowa). Jeśli organizacja nie poświęca uwagi rozwojowi wartości własnego wnętrza, czyli jednostek ją budujących, w zasadzie nie stwarza przestrzeni do rozwinięcia wartości moralnych, takich jak: poczucie lojalności, odpowiedzialności, szczerości czy otwartości komunikacyjnej. W efekcie morale organizacji sprowadzają się do sprawnego funkcjonowania jednostek w osiąganiu celów organizacyjnych, bez względu na to, w jaki sposób cele te są osiągane.

W kształtowaniu moralności w ujęciu integralnym należy łączyć podejście jednostkowe z kulturowym i systemowym wymiarem; błędem byłoby zaniedbanie choć jednej ze sfer. W praktyce łańcuch integralnych działań moralnych według czterech ćwiartek zaczyna się od łączenia ogniwa indywidualnego kośćca moralnego (ćwiartka intencjonalna), czyli spojrzenia na dane zagadnienie z perspektywy tego, co według jednostki (mnie) byłoby dobrym wyborem $\mathrm{z}$ ogniwem zasad wyznawanych przez inne osoby (ćwiartka kulturowa). Powstaje wówczas przestrzeń do interakcji i uzgadniania własnych poglądów oraz decyzji z decyzjami innych, wypełniona ustaloną w trakcie komunikacji intersubiektywną etycznością (Wight 2013). Uzgodnienia te ujęte $\mathrm{w}$ instytucjonalne procesy i kody stanowią kolejne ogniwo łańcucha (ćwiartka systemowa) łączące się z zachowaniami (ćwiartka behawioralna), czyli faktycznymi działaniami będącymi w zgodzie z założeniami danej wspólnoty i organizacji (Forman 2011).

Wspomaganie rozwoju etyczno-moralnego powinno odbywać się poprzez kształtowanie kompetencji wspomagających wzrost w wielu wymiarach. Dla rozwoju etycznego w szczególności ważne są (Harris i in. 2005, s. 19-20; Murray 2009, s. 2):

1) zdolność do dostrzegania dylematów etycznych w każdej sytuacji, nawet jeśli ta wymaga jedynie technicznego, czysto konstrukcyjnego rozpatrzenia (przykładowo stworzenia oprogramowania komputerowego), etyczne bowiem podłoże nie zawsze jest doskonale widoczne;

2) zdolności analityczne niezbędne do przeprowadzania sprawnej analizy etycznej, jak myślenie krytyczne i syntetyczne czy szybkie identyfikowanie obszarów porozumienia dla niezgodności i kontrowersji;

3) zdolność do tolerowania niejednoznaczności i rozbudzanie zrozumienia faktu, że nie ma jednej gotowej odpowiedzi na różnorodne pytania moralno-etyczne;

4) angażowanie moralnej wyobraźni w celu unaocznienia możliwych konsekwencji i wszelkich możliwych perspektyw oglądu danego zjawiska; 
5) rozbudzenie poczucia odpowiedzialności, poczucia autentycznej troski i moralnej powinności.

\section{Zakończenie}

Wilber wymienia trzy powody, dla których sztuka integralnego życia etycznego jest cenna $\mathrm{z}$ jednostkowego punktu widzenia:

1) mieć poczucie Boga poprzez czynienie Boga - czynienie dobra minimalizuje poczucie splątania i uwikłania, które dominuje w przypadku osób żyjących poza granicami etyki (np. osób, które oszukują, zdradzają). Czynienie Boga wzmaga utrzymywanie jasnej i „czystej świadomości oraz subtelnej energii ciała” (Wilber i in. 2008, s. 269).

2) transformacja ku wyższym stanom świadomości - wyrażanie etycznej intencji jest procesem jednoczenia się z innymi przez obieranie ich perspektyw, przyczynia się przez to do transformacji naszej świadomości. W akcie jednoczenia się w perspektywie innej osoby wyraża się nie tylko głęboka chęć współistnienia i pomocy, ale unaocznia się także nasza własna metamorfoza. Rozwój etyczny przechodzi przez stadia, od prostego pojmowania ukształtowanych kulturowo zasad, uczących odróżniania dobra od zła (stadium konwencjonalne), ku stadiom wyższym. Następnym stadium jest okres, w którym etyczne ramy zaczynają przerastać dychotomizującą rzeczywistość perspektywę dobry-zły, i jednostka zaczyna się zastanawiać nad mechanizmami i wzorcami leżącymi u podstaw szczęścia i jego braku, które zawiadują czynami człowieka. Etap ten prowadzi do rozwoju postkonwencjonalnych etycznych pobudek, które ujmują większość konwencjonalnych działań moralnych w szerszej perspektywie. Prowokuje to do ukształtowania myślenia w terminach paradoksów, odcieni szarości, antynomii, konkurencyjnych wartości. Dalsza ewolucja etyki integralnej powoduje wzrost zdolności do utrzymania niebosiężnej ilości sprzeczności, niekonsekwencji i nielogiczności

3) etyczne życie kreuje przestrzeń dla przebudzenia (awakening) z buddyjskiego karmicznego snu, wzrostu świadomości egzystencji. Im istota ludzka jest bardziej zaawansowana w rozwoju na wielu linach, tym głębiej odczuwa łączność ze wszystkimi bytami (ludźmi, nacjami, kosmosem).

\section{Bibliografia}

Esbjörn-Hargens S., Wilber K. (2006). Toward a comprehensive integration of science and religion: A post-metaphysical approach. W: P. Clayton, Z. Simpson (red.). The Oxford handbook of religion and science. Oxford: Oxford University Press.

Forman J. (brw). Ethical fitness trough moral dilemmas. Dostępny na: https:// www.integrallife.com/integral-post/ethical-fitness-through-moral-dilemmas (otwarto 11.02.2015). 
Gop A. (2015). Edukacja XXI wieku. Integralne nauczanie. „Ruch Pedagogiczny”, nr 4, s. 95-104.

Harris C.E., Pritchard M.S., Rabins M.J. (2005). Engineering ethics: concepts and cases. Belmont: Wadsworth Publishing.

Kelly S. (brw). Sources of the good: Towards a complex-integral ethic for the planetary era. Dostępny na: http://integralpostmetaphysicalnonduality.blogspot. com/2015/o1/integral-ethics.html (otwarto 16.02.2015).

Kielar M.B. (2014). Idee edukacji integralnej w polskiej pedagogice. Wystąpienie na VI Międzynarodowej Konferencji Pedagogiki Filozoficznej, Łódź, 17-19 października 2014.

Kielar M.B., Gop A. (2012). Integralny Pluralizm Metodologiczny. Teoria i badania naukowe. Warszawa: Wydawnictwo Akademii Pedagogiki Specjalnej.

Kielar M.B. (2012). Integralna wizja Kena Wilbera i jej zastosowanie w edukacji. Warszawa: Wydawnictwo Akademii Pedagogiki Specjalnej.

Murray T. (2010). Exploring Epistemic Wisdom: Ethical and Practical Implications of Integral Theory and Methodological Pluralism for Collaboration and KnowledgeBuilding. W: S. Esbjörn-Hargens (red.). Integral Theory in Action: Applied, Theoretical, and Constructive Perspectives on the AQAL Model. Albany: Suny Press.

Murray T., Ake J., Peterson M.J. (2009). Online Curriculum and Dialog Design for Ethics Skills for Science and Engineering Students. Dostępny na: http://www. perspegrity.com/papers/E-LearnogMurrayExt.pdf (otwarto 11.10.2015).

Murray T. (brw). An Introduction to Principles of Ethics and Morality for Scientists and Engineers. Dostępny na: http://www.umass.edu/sts/ethics/online/ EthicsResources/Eng_Ethics_intro.html (otwarto 10.10.2015).

Reynolds B. (2006). Where's Wilber At? Ken Wilber's Integral Vision in the New Millenium. Minnesota: Paragon House.

Waddock S. (2005). Mindfulness and integrity: The ongoing challenge of leadership development. W: R.A. Peterson, O.C. Ferrel (red.). Business ethics: New challenges for business schools and corporate leaders. New York: M.E. Sharpe.

Wight I. (2013). Exploring inter-being and inter-becoming as ethos making. „Journal of Integral Theory and Practice”, nr 8, s. 82-96.

Wilber K. (2000). Sex, ecology, spirituality: The spirit of evolution. Boston \& London: Shambhala.

Wilber K. (2006). Integral spirituality: a startling new role for religion in the modern and postmodern world. Boston \& London: Shambhala.

Wilber K. (2007). The Integral Vison. A Very Short Introduction to the Revolutionary Integral Approach to Life, God, the Universe, and Everything. Boston \& London: Shambhala.

Wilber K. (1997/2012). Krótka historia wszystkiego, tłum. H. Smagacz. Warszawa: Wydawnictwo J. Santorski \& Co. 
Wilber K., Patten T., Leonard A., Morelli M. (2008). Integral Life Practice: A 21st-Century Blueprint for Physical Health, Emotional Balance, Mental Clarity, and Spiritual Awakening. Boston\&London: Shambhala.

Wilber K. (brw). What is integral spirituality?. Dostępny na: http://files.meetup. com/91062/Integral\%2oSpirituality.pdf 1 (otwarto 6.02.2015).

\title{
KEN WILBER'S CONCEPT OF INTEGRAL ETHICS AND ITS IMPLICATIONS FOR PEDAGOGY
}

\begin{abstract}
This article tackles the topic of integral ethics by a modern American philosopher Ken Wilber. The paper discusses Wilber's analysis of the stages of moral development. It also describes main concepts of integral ethics and points out the possible applications of the integral model in the current Polish pedagogical discourse.

Keywords: Ken Wilber, moral development stages, integral ethics, values.

Aneta Gop - doktor nauk humanistycznych w zakresie pedagogiki, adiunkt w Zakładzie Metodologii i Pedagogiki Twórczości w Akademii Pedagogiki Specjalnej im. M. Grzegorzewskiej. Autorka publikacji z zakresu praktycznej realizacji teorii integralnej Kena Wilbera i współautorka pierwszej w Polsce monografii poświęconej integralnemu pluralizmowi metodologicznemu: Kielar M.B., Gop A., Integralny Pluralizm Metodologiczny. Teoria i badania naukowe, Wydawnictwo Akademii Pedagogiki Specjalnej, Warszawa 2012. Adresy mejlowe: agop@aps.edu.pl, aneta.gop@gmail.com.
\end{abstract}

